\title{
Conference Information
}

\section{Towards Developing Contemporary Education Theory}

The International Institute of Islamic Thought (Washington) and

The Islamic Studies and Research Association (Amman)

Amman, Jordan

Muharnam 3.6. 14LJuly 24-26, 1990

With the increased interest in Islamic countries to adopt a way of life based on Islamic law, the need has intensified for practical and scientific Islamic alternatives to social and economic problems facing the world in general and the Islamic nations in particular.

Most countries of the world are undergoing severe education crises and reform is especially needed in education. The education systems in many countries have failed to develop the individual in relation to social and humanistic goals. Educational systems in the Islamic countries have been mostly modeled on those of Western countries. As a result, these Islamic countries are undergoing dual crises. First, the adopted education systems have had a severe impact on many aspects of daily life in the Islamic countries. Second, the adopted education systems frequently counter Islamic goals and ideals.

Numerous thinkers and intellectuals in Muslim countries have emphasized the role of education in building a balanced and integrated individual personality in society. Hundreds of books were written discussing these issues. Various conferences were held to restore educational thought from the Islamic heritage. The effects of these efforts has resulted in emphasizing the successful role of Islamic education in shaping the person, rebuilding society, and contributing to civilization.

Education in modern society plays an important role in training human resources to bridge the economic gap between the developed and developing countries. Therefore, there is an intense need to form a clear method for 
education specialists in Muslim societies by which to implement educational theory in specific action programs.

Most Muslim countries are currently going through a critical stage. These countries, in their attempts to free themselves from foreign education systems, are looking to their education specialists to lead the way and show the capability of Islamic educational thought to encompass these changes.

This conference, "Towards Developing Contemporary Education Theory," represents a serious and continuous attempt to develop scientific and practical approaches to these challenges and to present feasible and applicable alternatives.

We hope that the conference will provide an opportunity for a large number of scientists and specialized researchers to discuss these issues and develop some alternatives. In addition, the conference will aim at emphasizing the originality of Islamic education in its theoretical and practical aspects. The following is a breakdown of the topics of discussion \& research:

First: Review of written literature on Islamic thought, analysis, and adaptation. The literature includes:
a. Published books.
b. Published research in centers' and universities' periodicals and bulletins.
c. Unpublished masters and doctoral dissertations.
d. Research papers and recommendations of specialized conferences.
e. Unpublished manuscripts.

Special committees are asked to undertake the above review.

Second: A contemporary Islamic look towards components of the education process:

1. Goals:
a. Islamic education based on the Prophet's behavior as the ideal criteria.
b. Sources of general educational goals and their relation to Islamic education philosophy and the order of society; their relation to Islamic personality and character, and their relation to different aspects of humanity.
c. Different goals of general education, information, performance, and intuition.


d. Levels of general educational goals in connection with education stages, subjects, and types.

e. Education goals and their relation to the labor market and development.

2. The Educated (student):

a. Student characteristics: Islamic educational goals in building ideal Islamic personality (balanced, practical, and integrated).

b. Aspects of Islamic personality (spiritual, belief and worship, intellectual, social, etc.).

c. Individual requirements during developmental stages; Islamic perceptions of growth requirements as studied by contemporary psychologists, growth costs, teenage factors.

d. Factors and problems affecting the formation of Islamic personality and its role in understanding the Muslim personality in modern society.

3. The Program:

a. Islamic understanding of an educational program and the role of Islamic education in the content of an educational program.

b. Components of an Islamic program within the desired Islamic identity: aims, content, activities, means, and technology of educational development.

c. Education planning (areas and types of education in different stages of education).

d. Language teaching within an Islamic program: importance of the Arabic language for Arabs and non-Arabs, as a mother tongue of the society; international languages and their implications for developing Islamic personality.

e. Islamic concepts of science classificatons and their effects on the education plan.

f. Teaching art within an educational program.

g. Islamic criteria for research programs (history, sciences, etc.)

h. Vocational education within the Islamic education program. 
4. Education Organizations:

a. General education in the society and its basic components and environment.

b. Government education establishment and its role in education: schools and higher education institutions.

c. Preschool education establishments: family, kindergarten, nursery.

d. Establishment of parallel education and its role in the education process.

e. The role of the Holy Qur'an, mosques, clubs, community centers, mass media.

5. The Teacher:

a. Characteristics of the Muslim teacher.

b. Manners and morals of education as an occupation according to the Holy Qur'an, Al-Sunnah, and historical developments.

c. The role of the educator in parallel education establishments: The father, the mother, the mosque, etc.

6. Development:

a. Islamic concepts of educational development: Improving components of the education process (student, teacher, program, educational institution, etc.), educational development within the concepts of present and ongoing life.

Third: Towards Developing Contemporary Education Theory

1. Theory development within Western thought humanities and its relation to Islamic thought.

2. Islamic education theory: historical prospective, the need for the theory, how to develop the theory.

3. Sub-theories of education (theories of teaching, learning, curriculum, administration, etc.) and their role in developing overall education theory.

4. Means of Islamic research and its relation to modern and scientific research in education.

5. Developing Islamic education theory. 
NOTE: The Papers and The Language of The Conference will be Arabic.

For more information contact:

Dr. Ishaq Farhan

Islamic Studies and Research Association

P. O. Box 9489

Amman, Jordan

Tel: 6-639992

Fax: 2-240732

or

Dr. Mahmoud Rashdan

International Institute of Islamic Thought P.O. Box 669

Herndon, VA 22070, U.S.A.

Tel: (703) 471-1133, Ext. 261

Fax: (703) 471-3922 